\title{
KEANEKARAGAMAN SERANGGA POLLINATOR PADA BUNGA TANAMAN TOMAT (SOLANUM LYCOPERSICUM) DI KECAMATAN GISTING KABUPATEN TANGGAMUS
}

\section{${ }^{1}$ RIZKI FAJAR ANDRIAN, ${ }^{2}$ GRES MARETTA}

${ }^{1}$ Program Studi Pendidikan Biologi,Fakultas Tarbiyah Dan Keguruan, Universitas Islam Raden Intan Jl. H. Endro Suratmin Sukarame-Bandar Lampung (0721)703260, Email : rizkiandrian672@gmail.com

${ }^{2}$ Program Studi Pendidikan Biologi,Fakultas Tarbiyah Dan Keguruan, Universitas Islam Raden Intan Jl. H. Endro Suratmin Sukarame-Bandar Lampung (0721)703260, Email : gresmaretta@ radenintan.ac.id

Diterima: 19 Mei 2017. Disetujui : 19 Juni 2017. Dipublikasikan: 29 Juni 2017

\begin{abstract}
Abstrak: Serangga pollinator merupakan salah satu layanan jasa ekosistem yang sangat penting bagi manusia maupun lingkungan dan berperan sebesar 35\% penyediaan sumber pangan dunia. Tujuan penelitian ini untuk mengetahui keanekaragaman serangga pollinator yang ada di lahan perkebunan Gisting Kabupaten Tanggamus. Penelitian ini telah dilakukan di bulan september 2015. Identifikasi serangga dilakukan dengan menggunakan kunci identifikasi Michener (2001). dengan metode scan sampling.Berdasarkan penelitian yang dilakukan, temuan spesies serangga pollinator diperkebunan tomat Gisting Kabupaten Tanggamus sebanyak 17 individu yang berasal dari 4 genus,Colletes, Amegilla, Xylocopa dan Ceratina. Hasil perhitungan dari Indeks Keanekaragaman ShannonWiener di lokasi perkebunan tomat adalah 1.00, hasil tersebut dikategorikan Indeks sedang.
\end{abstract}

Kata kunci : serangga penyerbuk, keanekaragaman, identifikasi, perkebunan Gisting Tanngamus

\section{PENDAHULUAN}

Kehidupan di bumi merupakan sejarah interaksi antara mahluk hidup dan lingkungannya. Alam telah mengajarkan kepada kita beberapa peristiwa perubahan bentuk fisik dan kebiasaan mahluk hidup yang dibentuk oleh lingkungannya. Populasi mahluk hidup sangat penting di dalam ekosistem. Populasi serangga dapat berperan sebagai penyerbuk pada tanaman. Dalam lahan pertanian tidak lepas dari serangga. Serangga merupakan salah satu komponen keanekaragaman hayati. Serangga yang berada di lahan pertanian banyak jenisnya dan dapat berperan sebagai herbivora, karnivora, detrivor, dan pollinator. Di alam, serangga membantu penyerbukan sekitar dua per tiga dari total tanaman berbunga dan sekitar 400 spesies tanaman pertanian. Serangga yang berperan dalam penyerbukan tanaman adalah kumbang, lalat, lebah, tawon, kupu-kupu dan ngengat. Diantara serangga tersebut, lebah, merupakan agen penyerbuk paling penting. Lebah merupakan penyerbuk potensial tanaman tomat karena mampu menggetarkan kerucut benangsari. Lebah dianggap lebih effisisen dalam membantu penyerbukan tanaman pertanian, karena mampu meningkatkan stabilitas, kualitas dan jumlah layanan penyerbukan sepanjang waktu dan ruang 
dibanding dengan serangga lain. Ketertarikan serangga penyerbuk terhadap bunga tanaman dipengaruhi oleh berbagai faktor antara lain ukuran bunga, warna bunga dan jumlah bunga. Pada tanaman yang penyerbukannya dilakukan dengan bantuan serangga, bunga dikelilingi oleh corolla yang warna, bentuk dan susunannya berbeda antar spesies, yang ditujukan untuk menarik serangga penyerbuk. Selain itu ketertarikan serangga terhadap bunga juga dipengaruhi oleh ketersediaan nektar dan tepung sari serta kondisi bunga untuk serangga penyerbuk

Tomat tergolong buah multiguna dan multifungsi yang dapat di budidayakan di lahan dataran rendah atupun tinggi, disamping warnanya yang merah tomat memiliki vitamin yang berguna bagi tubuh yakni vitamin $\mathrm{C}$, Masalah utama tomat setelah dipanen adalah sifatnya yang mudah rusak oleh pengaruh mekanis serta kandungan air yang tinggi, sehingga memungkinkan adanya aktivitas enzim dan mikroorganisme pembusuk, Pada pasca panen atau saat penyimpanan, buah dapat mengalami susut fisik (penurunan bobot buah), susut kualitas (terjadi perubahan bentuk, warna, dan tekstur biah), serta susut nilai gizi (penurunan kadar asam organik dan vitamin)Tanaman tomat (solanum lycopersicum) adalah tumbuhan setahun, berbentuk perdu atau semak dan termasuk kedalam golongan tanaman berbunga (angiospermae). Bentuk daunya bercelah menyirip tanpa stippelae (daun penumpu). Jumlah daunya ganjil antara 5-7 helai. Disela sela pasangan daun terdapat 1-2 pasang daun kecil yang berbentuk delta, Menurut klasifikasi tumbuhan, tanamn tomat termasuk kelas dicotyledonnae (berkeping dua).

Kecamatan Gisting merupakan desa yang berada di daerah kaki gunung Tanggamus berada pada ketinggian $750 \mathrm{mdpl}$, di daerah ini termasuk daerah yang dingin dengan kisaran suhu $25^{\circ} \mathrm{c}$, dengan curah hujan $2500 \mathrm{~mm}$ dan bulan hujan sebanyak 7 bulan. Luas tanah perkebunan pada desa ini sekitar 25 ha dan persawahan sekitar 55,8 ha. Menurut data kelurahan yang ada luas komoditas sayur sayuran mencapai 12,5 ha dengan hasil panen 7 ton/ha. Dari data data tersebut dapat menggambarkan bahwa Kecamatan Gisting khususnya desa Landbaw merupakan daerah pertanian dan banyak dari masyarakat setempat menggantungkan hidupnya dari lahan pertanian yang subur

\section{METODE PENELITIAN \\ Waktu dan Tempat}

Penelitian inidilaksanakan pada bulan September 2015 di Kecamatan Gisting Kabupaten Tanggamus, dan luas perkebunan yang akan diteliti kurang lebih $250 \mathrm{~m}^{2}$, Selanjutnya setelah mendapatkan sampel serangga, identifikasi dilakukan di laboratorium Biologi IAIN Raden Intan Lampung

\section{Metode Penelitian}

Keanakeragaman serangga pollinator diamati pada 250 tanaman tomat yang sedang berbunga dengan metode scan samplingyaitu salah satu metode untuk menghitung jumlah spesies dan individu serangga pengunjung. Pengamatan keanekaragaman serangga dilakukan pada tiga periode waktu, yaitu pukul 07.0008.59, 09.00-11.00, dan 13.00-16.00 WIB saat cuaca cerah atau tidak hujan, Jumlah spesies dan individu serangga yang mengunjungi bunga tomat dicatat. Beberapa individu serangga yang mengunjungi bunga tomat dikoleksi dengan insect net. 


\section{Alat dan Bahan}

Alat dan Bahan yang digunakan dalam penelitian ini meliputi: botol sampel, kantong plastik, alkohol 70\%, mikroskop, kamera, alat tulis, insect net , kertas label dan oven.

\section{Cara Kerja}

\section{Tahap persiapan}

Tahap persiapan ini diawali dengan menyiapkan peralatan yang digunakan untuk pengambilan sampel, penelitian ini menggunakan metodescan sampling. Peneliti akan menggunakan insect netdengan menelusuri perkebunan tomat guna mencari serangga untuk keperluan identifikasi.

2. Tahap Pelaksanaan

a. Melakukan tahapan persiapan dengan menyiapkan alat-alat pengambilan sampel.

b. Mengambil sampel serangga yang terdapat pada lahan perkebunan tomat dengan menggunakan insect netuntuk keperluan identifikasi.

c. Memasukkan sampel-sampel serangga yang telah ditemukan ke dalam botol sampel yang berisi alkohol $70 \%$.

d. Mengidentifikasijenis-jenis serangga di Laboratorium Biologi IAIN Raden Intan Lampung.

\section{Pengambilan Sampel}

Pengambilan sampel berdasarkan banyaknya spesies serangga yang ditemukan. Spesimen di masukkan ke dalam botol sampel yang berisi alkohol 70\%. Selanjutnya spesimen di awetkan secara keringberdasarkan Triplehorn dan Johnson. Spesimen serangga ditusuk menggunakan jarum serangga, kemudian dimasukkan dalam oven dengan suhu $35^{\circ}$ Cselama tujuh hari. Setelah spesimen dikeluarkan dari oven, spesimen diberi label kemudian dimasukkan ke dalam kotak dan disimpan dalam lemari pendingin selama tujuh hari untuk mensterilkan spesimen. Setelah steril, spesimen dibawa ke ruang koleksi dan diidentifikasi. Selain itu jika mendapatkan serangga yang cukup besar akan di awetkan secara insektarium.

4. Identifikasi Serangga

Sampel serangga yang diperoleh akan diidentifikasi di Laboratorium Biologi IAIN Raden Intan Lampung. Untuk menghindari pemberian nama baru terhadap spesies serangga yang ditemukan di Wilayah Kecamatan Gisting Kabupaten Tanggamus, maka peneliti melakukan identifikasi spesies yang didapat berdasarkan pada kunci identifikasi dan Michener. Pengidentifikasian serangga hanya sampai pada tingkat genus.

\section{Teknik Analisis Data}

Analisa struktur komunitas serangga meliputi keanekaragaman (shanonwiener). Rumus- rumus yang digunakan adalah sebagai berikut :

Keanekaragaman Shanon-Wiener $\left(\mathrm{H}^{\prime}\right)$

$\mathrm{H}^{\prime}=-\sum$ pi ln pi

Keterangan :

$\mathrm{H}^{\prime}=$ Indeks keragaman Shanon

$\mathrm{Pi}=$ proporsi kelimpahan jenis ke-i (ni/N)

Kriteria indeks keanekaragaman Shanon-Wiener dibagi menjadi 3 yaitu 
$\mathrm{H}^{\prime}<1=$ Keanekaragaman rendah

$1<\mathrm{H}^{\prime}<3=$ Keanekaragaman sedang

$\mathrm{H}^{\prime}>3$ = Keanekaragaman tinggi

\section{HASIL PENELITIAN DAN PEMBAHASAN \\ Hasil Penelitian}

Berdasarkan penelitian yang dilakukan di lahan pertanian tomat di Kecamatan Gisting Kabupaten Tanggamus di dapat 4 Genus, yaitu Colletes ,Amegilla, Xylocopa dan Ceratina, dan berdasarkan penelitian, sampel dari GenusAmegilla paling banyak ditemukan dengan 11 ekor, GenusColletes 2 ekor, Genus Xylocopa 3 ekor, Genus Ceratina 1 ekor. Genus yang paling banyak ditemukan pada waktu pagi dan siang hari, ketika sore hari sedikit sekali serangga yang ditemukan, kadang tidak menemukan serangga. Puncak kunjungan serangga terjadi pada pukul $08.30-10.30$.

Keragaman serangga pollinator bisa dilihat pada table 1 dibawah ini.

Table 1. Indeks Serangga Pollinator Pengunjung Bunga Tanaman Tomat

\begin{tabular}{|l|c|c|c|c|}
\hline Genus & $\begin{array}{c}\text { Pagi } \\
(\mathbf{0 7 . 0 0 - 0 9 . 0 0 )}\end{array}$ & $\begin{array}{c}\text { Siang } \\
(\mathbf{1 0 . 0 0 - 1 2 . 0 0 )}\end{array}$ & $\begin{array}{c}\text { Sore } \\
(\mathbf{1 3 . 0 0 - 1 5 . 0 0 )})\end{array}$ & \\
\hline Amegilla & 2 & 9 & 0 & 11 \\
\hline Colletes & 0 & 2 & 0 & 2 \\
\hline Xylocopa & 0 & 3 & 0 & 3 \\
\hline Ceratina & 0 & 1 & 0 & 1 \\
\hline Jumlah & \multicolumn{3}{|r}{} \\
\hline
\end{tabular}

\section{Kondisi Fisik Lingkungan Penelitian dan Hasil Temuan}

Lokasi pencarian sampel memiliki ketinggian $750 \mathrm{~m}$ diatas permukaan laut dan suhu udara berkisar $25^{\circ} \mathrm{c}$, Hal ini tentunya sangat mendukung wilayah ini sebagai tempat hidup serangga karena suhu di wilayah ini tergolong rendah.Semua serangga adalah berdarah dingin (Poikilotherms) dimana serangga membutuhkan panas dari lingkungan sekitar untuk memulai proses metabolismenya, Serta lingkungan sekitar merupakan daerah perkebunan warga sekitar, lokasi pencarian sampel sekitar $250 \mathrm{~m}^{2}$ dan total sampel serangga yang ditemukan 17 dari 4 genus yaitu GenusAmegilla,Colletes, Xylocopa, dan Ceratina.

Tabel 2. Indeks Keanekaragaman Shannon-Wiener $\left(\mathrm{H}^{\prime}\right)$ di lokasi perkebunan tomat

\begin{tabular}{|l|l|l|l|l|l|l|}
\hline No & Genus & Pi & pi2(kuadrat) & n(n-1)/N(N-1) & ln pi & pi ln pi \\
\hline 1 & Amegilla & 0,64705 & 0,418673785 & 103,52941176 & $-0,4353$ & 0,28167 \\
\hline 2 & Colletes & 0,11764 & 0,013839169 & 1,8823529412 & $-2,1402$ & 0,25178 \\
\hline 3 & Xylocopa & 0,17647 & 0,031141660 & 5,6470588235 & $-1,7346$ & 0,30611 \\
\hline 4 & Ceratina & 0,05882 & 0,003459792 & 0 & $-2,8332$ & 0,16665 \\
\hline Jumlah & 0,99998 & 0,467114406 & 111,05882352 & $-7,1433$ & 1,00621 \\
\hline
\end{tabular}


Dari tabel 2 diatas menunjukkan bahwa Analisis struktur komunitas serangga pollinator pada perkebunan tomat meliputi keanekaragaman (ShannonWiener) dengan Indeks keanekaragaman $\mathrm{H}^{\prime}=-\sum$ pi $\mathrm{In} \mathrm{pi}=1.00$, hasil tersebut dikategorikan Indeks sedang. Terbukti dengan ditemukannya 4 genus serangga pollinator pada perkebunan tomat.

\section{Pembahasan}

GenusColletes terdapat corak hitam kuning. berukuran kurang lebih 5 $\mathrm{mm}$ dan dilihat dari bagian bawah kepala nya serangga ini berwarna kuning kecoklatan, memiliki tiga sel submarginal di depan sayap serta kaki kaki dari serangga ini berbulu padat dan cakar tarsal, mata tidak terlalu majemuk, abdomen dari serangga ini pun di penuhi bulu yang padat sayap nya tranparan dan sayapnya berukuran lebih dari $1 \mathrm{~mm}$.

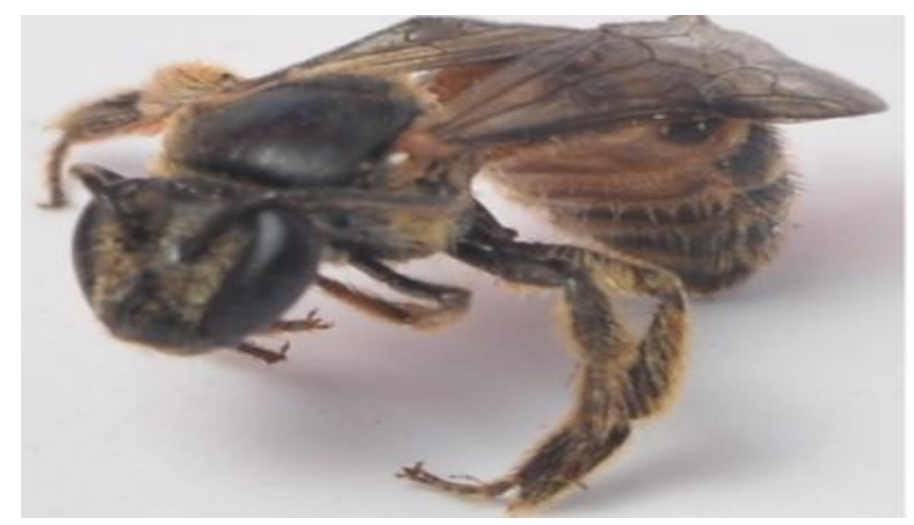

Gambar 1 GENUS COLLETES

Glossa pada genus Colletes pendek dan pada umumnya lebih luas yang berfungsi untuk memotong, memiliki celah celah kadang di tarik kedalam dan jika menjulur keluar mamanjang menjadi dua, permukaan glossal berbentuk seperti cincin (anulate) masuk dalam zona apical, yang biasanya berkembang menjadi lobus besar yang mencolok dan memiliki bulu bulu beraturan seperti sikat, jarak dan permukaan annulate biasanya ditandai dengan preapical.

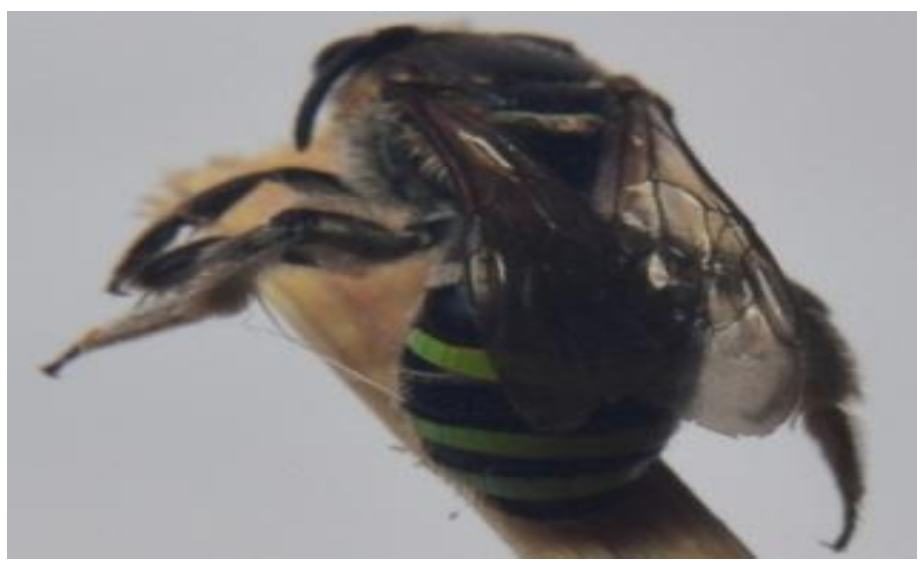

Gambar 2 GENUS AMEGILLA

Genus Amegilla berkisar 11 ampai $13 \mathrm{~mm}$, ada tanda kuning di sepanjang labrum, dan garis medial di kepala, Margin apikal segmen perut 1-4 ditutupi 
rambut biru metalik, kaki - kaki serangga ini ditutupi oleh bulu-bulu metalik, pada abdomen Genus Amegilla terdapat corak hijau hitam metalik. GenusAmegillayang termasuk dalam family Apidae merupakan salah satu lebah yang paling tinggi keanekaragamannya. Amegilla terdiri dari lebah sosial, lebah soliter dan lebah komunal. Banyak lebah Amegilla memiliki alat mulut yang telah termodifikasi menjadi proboscis, yang memungkinkan untuk menghisap nektar. Amegilla juga memiliki tungkai yang berseta dan kantong polen pada tungkainya. Sudut belakang pronotum tidak dekat tegula, antenna 13 ruas atau kurang. Mempunyai sikat pengumpul tepung sari pada kaki depan dan keranjang pembawa tepung sari pada kaki belakang, lebah ini dapat ditemukan di tanah, liang liang, kayu, atau di pertanaman yang sedang berbunga.

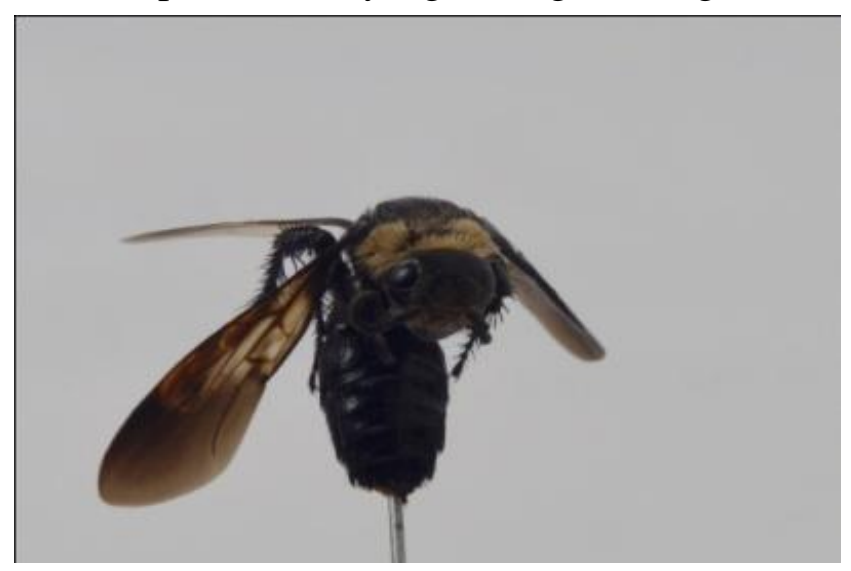

Gambar 3. GENUS XYLOCOPA

Genus ketiga yang di dapat adalah genus xylocopa, serngga ini cukup besar disbanding dengan temuan serangga sebelumnya panjang tubuhnya berkisar antara 20 sampai $23 \mathrm{~mm}$. Warna tubuh serangga ini hitam dan ada bulu -bulu putih di belakang kepalanya, sayap nya berwarna coklat transparan, memiliki bulu bulu diseluruh tubuh nya dan cakar tarsal pada kaki, serta memiliki mata majemuk, Lebah ini biasanya terbang dengan berdengung rendah keras. Hampir semua spesies dari GenusXylocopa ini membuat sarang di kayu-kayu mati dan bambu (kecuali pada subgenus Proxylocopa, yang bersarang di tanah). Xylocopa mencapai 730 spesies di seluruh dunia terutama negara yang beriklim tropis dan subtropis, lebah Xylocopa adalah polinator (penyerbuk) yang sangat penting karena terkait dengan perannya dalam rantai kehidupan alam di dunia.

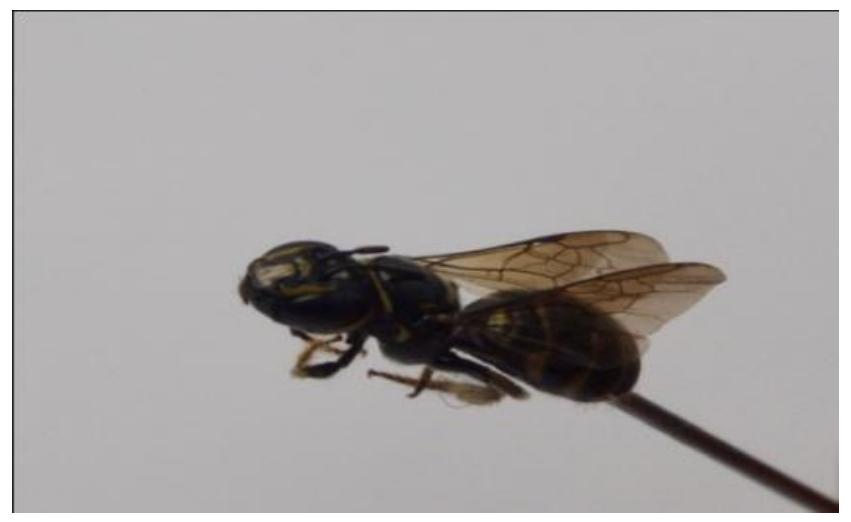

Gambar 4. GENUS CERRATIN 
Lebah terakhir yang juga tergolong pada family apidae ini lebah yang paling sedikit di dapat namun memiliki corak yang cukup menarik pada seluruh tubuhnya dengan corak warna kuning dengan rambut yang ada pada tubuhnya cukup jarang dan scope pada tibia belakang Spesies ini juga memiliki cakar tarsal pada kaki yang berguna untuk mengambil nectar pada bunga, memliki ruas ruas pada antenna nya sekitar 12 ruas. Ceratina memiliki puncak darisel marginal yang bisa dibengkokkan jauh dari costa, dan tidak adasternum Scopa kecuali dalam subgenus Catoceratina, panjang tubuh berkisar 3,0 - 12,5 mm

\section{KESIMPULAN DAN SARAN SIMPULAN}

Berdasarkan penelitian yang telah dilaksanakan,temuan serangga pollinator sebanyak 17 individu dari 4 genus serangga yaitu Amegilla, Colletes, Xylocopa, dan Ceratina. Nilai indeks keanekaragaman disetiap lokasi penelitian termasuk kategori sedang denganH' $=-\sum$ pi In $\mathrm{pi}=1.00$, Hal tersebut terbukti dengan ditemukan 4 genus serangga pollinator.

\section{SARAN}

Berdasarkan penelitian yang telah dilakukan, ada beberapa hal yang dapat menjadi bahan rekomendasi antara lain adalah sebagai berikut :

Perlu adanya penelitian lebih lanjut tentang jumlah populasi,dan keanekaragaman spesies serangga di Wilayah Provinsi Lampung, Khususnya di sekitar Kabupaten Tanggamus yang kita ketahui memiliki daerah perbukitan dan hutan lindung yang luas. Tentunya dengan adanya penelitian lanjutan, untuk ke depannya bisa menambah wawasan para peneliti dan berpotensi menemukan spesies-spesies tertentu yang sulit ditemui di wilayah lain ataupun spesies baru

\section{UCAPAN TERIMAKASIH}

Penulis mengucapkan terima kasih kepada para petani di perkebunan tomat Gisting Tanggamus dan seluruh dosen IAIN Raden Intan Lampung Program Studi Pendidikan Biologi.

\section{DAFTAR PUSTAKA}

Arintha Traya.P.S ,2013, Keanekaragaman Ordo Hymenoptera Di Perkebunan Kelapa Sawit, Perkebunan Karet Dan Hutan Karet Di Jambi, Bogor, departemen biologi Fakultas Matematika Dan Ilmu Pengetahuan Alam Institut Pertanian Bogor.

Arsyad.A.,2013, Media Pembelajaran (edisi revisi), Jakarta,PTRajaGrafindo Persada.

Data desa Landbau Kecamatan Gisting tahun 2015.

Dwiyono.A, Jasmi,Safitri.E., 2014,Studi Morfometrik Lebah Tukang Kayu xylocopa confusa linn. (hymenoptera: anthophoridae) Pada Dua Ketinggian Di Sumatera Barat,Padang,STKIP PGRI Sumatera Barat.

Fajarwati,M.R., Atmowidi,T., Dan Dorly., 2009,Keanekaragaman Serangga PadaBunga Tomat (lycopersicon esculentum mill.)di Lahan Pertanian Organic,Bogor, Departmen Biologi, Fakultas Matematika dan Ilmu Pengetahuan Alam Institut Pertanian Bogor, 
Hamdayama,Jumanta,2014,Model Dan Metode Pembelajaran Kreatif DanBerkarakter, Bogor, Ghalia Indonesia.

Hisyam, Keanekaragaman Jenis Serangga Pengunjung Tanaman Tomat (Lycopersicumesculentum L) Pada Masa Tanam Sebelum, Saat, dan Setelah Berbunga di Lahan Pertanian Ngemplak, Sleman, DIY.

Hasbulloh, 2005,Dasar Dasar Ilmu Pendidikan, Jakarta ,Raja Grafindo Persada.

Hisyam, Keanekaragaman Jenis Serangga Pengunjung Tanaman Tomat (Lycopersicum esculentum L) Pada Masa Tanam Sebelum, Saat, dan Setelah Berbunga di Lahan Pertanian Ngemplak, Sleman, DIY.

Kanisius, 1991, Kunci Determinasi serangga. Yogyakarta Kartikawati, N.K.,Pollinator Pada Tanaman Kayu Putih, Yogyakarta Jurnal balai Besar Penelitian Bioteknologidan Pemuliaan Tanaman Hutan Yogyakarta.

Mahfudho.a.f,Rahayu.s.e,Rohman.f,2014, Kajian Bioekologi Serangga Hama di Perkebunan Apel (malus sylvestris mill) Desa Tulungrejo Kecamatan Bumiaji Kota Batu, Malang, Fakultas Matematika dan Ilmu Pengetahuan Alam, Universitas Negeri Malang.

Michener CD.,2007, The Bees of the World. Baltimore. The John Hopkins Univ Pr.

Budi Purwantiningsih,2014,Serangga Polinator, Malang, UB press.

Rahmawati.I.S, Hastuti.E.D, Darmanti.S, 2011, Pengaruh Perlakuan Konsentrasi Kalsium Klorida $(\mathrm{CaCl} 2)$ dan Lama Penyimpanan terhadap Kadar Asam Askorbat Buah Tomat (Lycopersicum esculentum Mill.), Semarang, Biologi Fakultas MIPA UNDIP.

Rizali.A.,Buchori.D.,Triwidodo.H.,Keanekaragaman Serangga Pada LahanPersawahan-Tepian Hutan: Indikator Untuk Kesehatan Lingkungan”, Bogor, Jurusan Hama dan Penyakit Tumbuhan, Faperta, Institut Pertanian Bogor.

Sembel,D.T., 2010, Pengendalian Hayati, Yogyakarta , Andi Offset.Sudiana,E.

Suryanto Eko, 2015,Studi Arsitektur Sarang- Sarang Rayap Tanah Microtermes Gilvus Hagen (Isoptera: Termitidae) Dikecamatan Bumi Agung Kabupaten Waykanan, Bandar Lampung, Fakultas Tarbiyah Dan Keguruan Iain Raden Intan.

Syakur Abdul,2012, Pendekatan Satuan Panas (Heat Unit) Untuk Penentuan Fase Pertumbuhan Dan Perkembangan Tanaman Tomat Di Dalam Rumah Tanaman (Greenhouse), Palu, Fakultas Pertanian Universitas Tadulako

Sudiana,E. Widhiono,I.,2015, Keragaman Serangga Penyerbuk dan Hubunganya dengan Warna Bunga pada Tanaman Pertanian di Lereng Utara Gunung Slamet, Jawa Tengah, Purwokerto, Fakultas Biologi Universitas Jenderal Soedirman

S. Margono. Metodologi Penelitian Pendidikan. Rineka Cipta, Jakarta, 2000.

Sri Pujianto. Menjelajah Dunia Biologi untuk kelas XI SMA dan MA 2. Solo: Platinum, 2012.

Statistik untuk Penelitian (Cet. XXIII). Bandung: Alfabeta, 2013.

Sudjana. Metoda Statistika. Tarsito: Bandung, 2005.

Sugiyono. Metode Penelitian Pendekatan Kuantitatif Kualitatif dan R\&D (Cet. X). Bandung: Alfabeta, 2008.

Suharsimi Arikunto. Dasar-dasar Evaluasi Pendidikan Edisi 2 (Cet. IV). Jakarta: Bumi Aksara, 2015. 
Tim Bina Karya Tani, 2009, PedomanBertanam Tomat, Bandung, yrama widya. Tugiyono,H, 1986,Bertanam Tomat, Jakarta, penebaar swaday

Udin S Winataputra. Strategi Belajar Mengajar IPA. Jakarta: Universitas Terbuka, 2001.

Undang-undang Republik Indonesia. Sistem Pendidikan Nasional No. 20. Jakarta: Sinar Grafika, 2003.

Wahab Jufri. Belajar dan Pembelajaran Sains. Bandung: Pustaka Reka Cipta, 2013.

Wina Sanjaya. Strategi Pembelajaran Beroirentasi Sandar Proses Pendidikan Edisi Pertama (Cet. I). Jakarta: Kencana Prenadamedia Group, 2006.

Widhiono,I.,2015, Keragaman Serangga Penyerbuk dan Hubunganya dengan Warna Bunga pada Tanaman Pertanian di Lereng Utara Gunung Slamet, Jawa Tengah, Purwokerto, Fakultas Biologi Universitas Jenderal Soedirman

Winatasasmita Djamhur. Biologi Umum. Jakarta: Universitas Terbuka, 1999.

Wong Solo. "Menggunakan Keterampilan Berpikir untuk Meningkatkan Mutu Pembelajaran" (online), tersedia di: http://supraptojielwongsolo.wordpress.com/2008/06/13/menggunakanketerampilan-berpikir-untuk-meningkatkan-mutu-pembelajaran. htm (06 Maret 2016). 